韓国と日本で採集されたオオシャミセンガイ Lingula adamsi Dall, 1873 の 形態および遺伝子レベルの比較

\title{
Morphological and Genetic Comparisons between Lingula adamsi Dall, 1873 from South Korea and Japan
}

\author{
佐藤慎一 ${ }^{1), *}$ ・遠藤一佳 ${ }^{2)}$ ・ 山下博由 ${ }^{3)}$ \\ 1) 東北大学総合学術博物館. $7980-8578$ 仙台市青葉区荒巻字青葉 \\ 2) 筑波大学地球科学系. 干305-8571つくば市天王台 1-1-1 \\ 3) 貝類保全研究会. 干251-0038 藤沢市鵠沼松が岡 3-1-26-103
}

\author{
Shin'ichi SATO ${ }^{1)}$, Kazuyoshi ENDO ${ }^{2)}$ and Hiroyoshi YAMASHITA ${ }^{3)}$ \\ 1) The Tohoku University Museum. Aoba, Aramaki, Aoba-ku, Sendai 980-8578, Japan \\ 2) Institute of Geoscience, University of Tsukuba. Tennodai 1-1-1, Tsukuba, 305-8571, Japan \\ 3) Association of Conservation Malacology. Mastugaoka 3-1-26-103, Kugenuma, Fujisawa 251-0038, Japan
}

\begin{abstract}
Morphological and genetic traits of Lingula adamsi were compared among individuals from South Korea (Yellow Sea) and Japan (Ariake Sea). The Japanese population is usually identified as L. shantungensis, although this nominal species has been placed in synonymy with $L$. adamsi. Some studies have suggested that the Japanese population is a different species or subspecies from $L$. adamsi based on morphological comparisons. In this study, morphological characters of the shell of ten individuals of $L$. adamsi collected from southwestern South Korea, such as shape, color, and surface ornamentation, were compared with those of the Japanese population. Although the width/length ratio of the dorsal shell is significantly different between the South Korean and Japanese samples, this and all other morphological differences can be considered as intraspecific variation. The nucleotide sequences of the mitochondrial $\operatorname{cox} 1$ gene region indicate a very low level of variation between the ten South Korean individuals and an individual from the Ariake Sea, Japan, not greater than that observed within local populations of Lingula anatina. The forms from South Korea and Japan, therefore, are best interpreted as conspecific from the viewpoint of both morphological and genetic variation.
\end{abstract}

Key Words: Ariake Sea, Lingula adamsi, Lingula shantungensis, mitochondrial coxl gene, shell morphology, Yellow Sea.

\section{はじめに}

Lingula 属は,「生きた化石」の典型的な例として知られ る腕足動物であり，その化石記録は石炭紀までは確実に存 在し，オルドビス紀にも Lingula 属と思われる化石が見つ かっている (Cusack et al. 1999). 日本では, 中生代三畳紀 の山口県美袮層群や岡山県成羽層群などから Lingula 属に 同定される化石が発見されており（柳田ら 1995）, また，北 海道達布層群・宮城県須江層・岐阜県瑞浪層群・千葉県下 総層群などの第三系・第四系から Lingula 属の化石が多産 している (Shimakura \& Hatai 1939; Hatai 1954; Ohara 1969; 糸魚川ら 1976; Saito 2001).

Emig (1982) によれば, 現在 Lingula 属は世界中で 7 種

Received 13 Jan. 2004 Accepted 19 May 2004

*: Corresponding author
が分布するとされ，その中であオオシャミセンガイ Lingula adamsi Dall, 1873 (学名は Emig \& Hammond 1981 に 従った；後述）は最大で殼長 $7 \mathrm{~cm}$ に達し, Lingula 属とし てはL. tumidula と並んで世界最大の種である. 日本では, オオシャミセンガイは有明海奥部から諌早湾南岸にかけて （菅野 1980）と，熊本県天草郡松島町の前島之瀬島（山口 1980）で生息が確認されているほかは，山口県山口市長浜 (秋穂湾) において新鮮な（干涸びた肉のついた）片殸が確 認された（和田ら 1996; 福田宏 私信）のみであり, 和田ら (1996)により絶滅寸前と判断されている.

しかし，オオシャミセンガイの分類には多くの問題点が 残されている. そのひとつは学名の問題である. 日本では 内海 (1956) 以来, 有明海に分布するオオシャミセンガイ の学名には, Hatai (1937) により中国山東省産の標本を基 に記載されたL. shantungensis Hatai, 1937 が一般に使われ ている.これは, Emig \& Hammond (1981) により L. shantungensis がL. adamsi のシノニムであると指摘された以降 
も，ほとんど検討されることなくL. shantungensis が使用 されているケースが多い.

第 2 の問題は，両種の模式標本が紛失していることであ る. L. adamsi は, 朝鮮半島（産地：Tsaulian Harbor, Korean Archipelago, 7 fathoms) で得られた標本を, Adams (1863) がL. tumidula に同定した後に，Dall (1873) が同じ 標本を用いて再検討を行ない新種として記載したものであ る.しかし，現在では本種の模式標本は紛失しており， Emig \& Hammond (1981) により 新模式標本（産地：中国福 建省福州市) が設定されている。一方, 東北大学が所蔵す る L. shantungensis の模式標本 (IGPS No. 61311) む現在で は紛失しており，そのため Emig \& Hammond (1981) は両 種の模式標本を検討することなく Hatai (1937)の記載だ けを基にして本種を L. adamsi のシノニムと結論づけた.

さらに，菅野 (1980) と山口 (1981) は Hatai (1937) の記 載を根拠にして, 有明海産オオシャミセンガイと中国産 $L$. shantungensis とでは形態が若干異なるため，両者は別種か 別亜種の可能性があると指摘している。しかし，これまで 集団レベルで有明海産標本と中国・韓国産標本の形態・遺 伝学的解析結果の比較は行われたことがなく，これらの指 摘の妥当性を検討することができなかった。

本研究では, 韓国西海岸に扔いてオオシャミセンガイ 10 個体を得て，それらを有明海産オオシャミセンガイと形 態・遺伝子レベルで比較した。朝鮮半島で得られたオオ シャミセンガイ標本を用いた研究例は, Dall (1873)や Davidson (1888) らが L. adamsi の模式標本を検討して以 来，実に 100 年以上ぶりになる.

\section{調査地点と採集方法}

2003 年 9 月 28 日と 29 日に, 大韓民国全羅南道務安郡立 慶面龍井里 Wordo ( $\left.35^{\circ} 04^{\prime} 47.1^{\prime \prime} \mathrm{N}, 126^{\circ} 23^{\prime} 48.9^{\prime \prime} \mathrm{E}\right)$ におい て，オオシャミセンガイ 8 個体 (IGPS No. 109238-1〜8) を採集した (Fig. 1A)。この場所は，咸平 (Hampyeong) 湾 の湾央部にあたり，調查当日の干潮時（9月 29 日午前 9 時 20 分）における潮間帯下部の表層水塩分は $30 \sim 33$ psu で あった。 また，調査日の当地域周辺（木浦市）に打ける最 低潮位は，各々 $-16 \mathrm{~cm}$ (9月 28 日) と $-22 \mathrm{~cm}$ (9 月 29 日) であった。オオシャミセンガイを採集した地点は，満潮時 の海岸線加ら沖へ 100 $150 \mathrm{~m}$ の中潮帯下部加ら低潮帯付 近の干潟である (Fig. 2A).オオシャミセンガイは，軟泥底 において生息頻度が高かったが，砂泥底にも低密度ながら 生息していた。

採集地点には干潮時に徒歩で行き，オオシャミセンガイ の殼前縁が干潟表面に見えている個体を探した (Fig. 2C). 干潟表面には，オオシャミセンガイのものと思われるレン ズ状の穴が多数（1 $\mathrm{m}^{2}$ あたり 1 10 個程度，最も多い場所 では 20 個以上）見られた (Fig. 2B). しかし，この状態で は個体は堆積物中に深く潜り込んでいるため，穴を掘り起

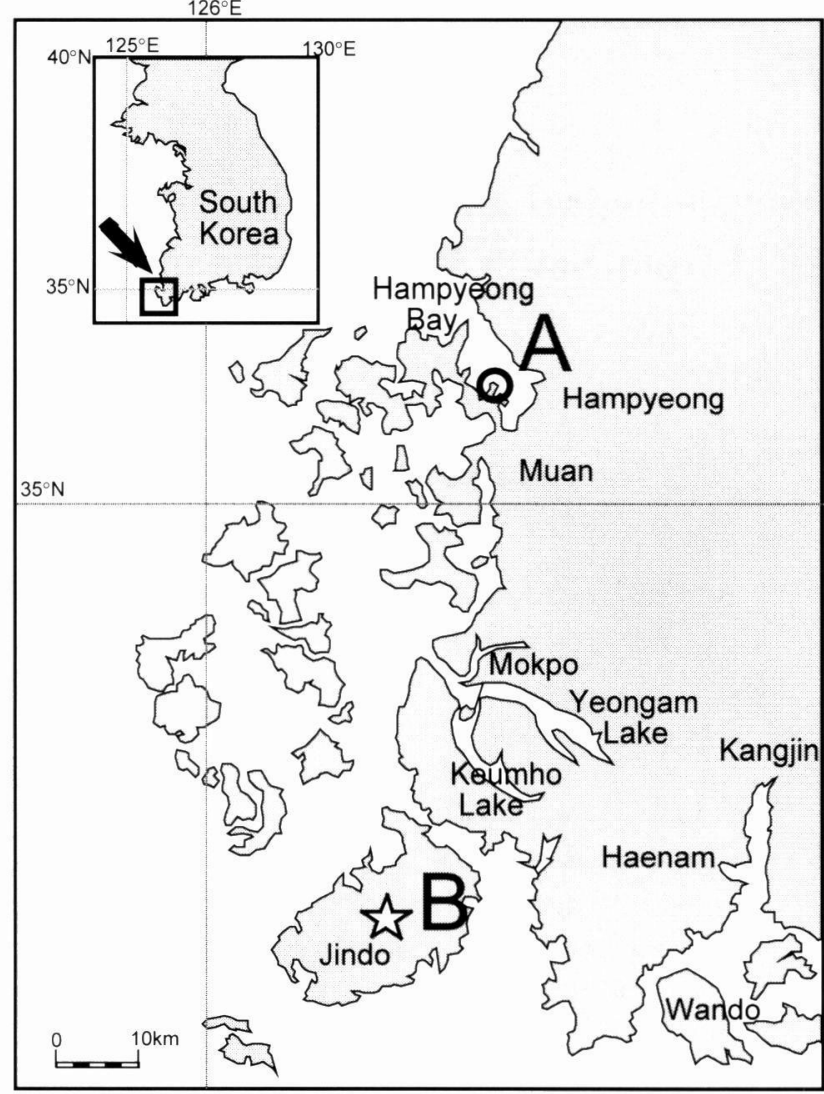

Fig. 1. Map showing the sampling localities. A: Wordo, Muangun, Jeonranamdo, South Korea. B: Jindo Island (market), Jeonranamdo, South Korea.

こしても採集できない。干潟表面に殼先端の見られる個体 は，せいぜい $10 \sim 100 \mathrm{~m}^{2}$ に 1 個体程度の割合である。才オ シャミセンガイの採集には小型のスコップを用いた。個体 の側面から斜めにスコップを刺して，個体が穴の中に潜れ ないようにしてから，肉茎がちぎれないように貝殼部分を 掴んでゆっくりと引き抜いた (Fig. 2D).このほか, 2003 年 5 月 2 日に同所で，また 2003 年 9 月 29 日に大韓民国全 羅南道珍島郡内の市場 (Fig. 1B) において, それぞれ 1 個 体（IGPS No. 109237 および 109239）を得た。これらの個 体は，すべて 95\%エチルアルコールで固定した。

龍井里 Wordo のオオシャミセンガイの生息地周辺では, ヒロオビヨフバイ Zeuxis succinctus, ヒナギヌ Bullacta exarata, サルボウ Scapharca kagoshimaensis, ヒメエガイ Nipponarca bistrigata, ヤミノニシキVolachlamys hirasei, カガ ミハマグリPitar (Pitarina) sulfureum, ウラカガミDosinia (Dosinella) angulosa な゙の貝類が生息し，チリメンュキガ イ Meropesta capillaceaの新鮮な殼も確認された。ミドリ シャミセンガイ Lingula anatina は生息していなかった。

また，龍井里 Wordo に生息するオオシャミセンガイに は, 高い率でウロコガイ科の 1 種 Galeommatidae gen. et sp. が寄生していた（ここでのウロコガイ科の定義は Ponder 1998 に従う)。韓国沿岸に生息するミドリシャミセン 

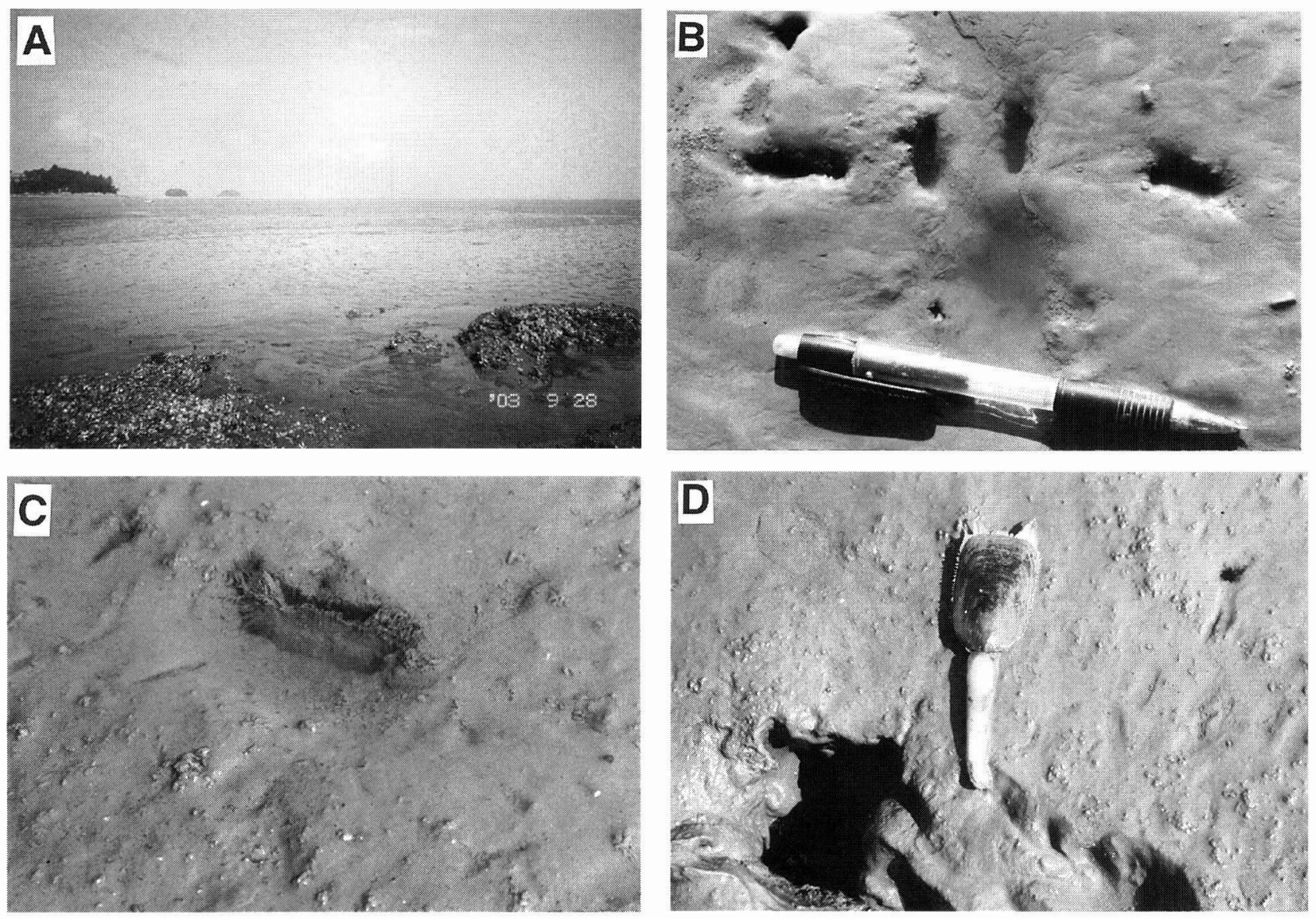

Fig. 2. Photographs of the sampling area in Wordo, Muan-gun, Jeonranamdo, South Korea from where Lingula adamsi were collected. A: muddy tidal flat of this area. Living individuals of $L$. adamsi were collected from the middle to lower intertidal shore. B: lenticular holes supposedly made by $L$. adamsi. C: living position of $L$. adamsi. D: whole body of $L$. adamsi collected from muddy tidal flat.

ガイには，ウロコガイ科の 1 種が寄生していることが知ら れており，韓国の研究者なよ゙によって記載準備が進められ ている (洪在上 私信). 今回確認されたオオシャミセンガ イに寄生する種は，ミドリシャミセンガイに寄生する種に 近似しているが，殼形態に差異が認められ別種の可能性が ある。

形態・遺伝学的比較に用いた有明海産オオシャミセンガ イ標本は，1992 年 8 月 29 日に福岡県柳川市沖ノ端で採集 した。得られた 2 個体のうち 1 個体を遺伝的解析に用いた (Endo et al. 2001). また, 有明海および中国産オオシャミ センガイの殼形態の計測值を, Hatai (1937), 菅野 (1980), 山口 (1980), および Emig \& Hammond (1981) から引用し た。

\section{殼形態の比較}

韓国で採集した個体 (IGPS No. 109238-1～8，109239) は, 殻形態の観察および湿重量を計測した後に, 背殻 (dorsal shell) の殼長と殼幅，および両殼の殼厚を，ノギスを用 いて計測した，腹殼 (ventral shell) は, 背殼に比べるとわず かに殼長が大きいが，殼後端が肉茥に埋もれていることが
多いため, 腹殼長の計測を正確に行うことはできなかっ た。

\section{殼の外形}

韓国で得られた個体は，成長段階によって殼外形が異な ることが確認された，すなわち，背壳長が 40～50 mm の段 階では全体的に小判型で丸みをおび，殼の前後縁に向けて 殼幅が狭くなり，前縁も曲線状である。一方，背殼長 50 $\mathrm{mm}$ 以上の個体は一般に角張った長方形に近く，壳前縁に むけて款幅は広くなり，殻前縁も直線に近くなる。これら の個体発生に伴う形態変異の特徵は, Emig and Hammond (1981) によるL. adamsi の記述と一致する.

L. adamsi の原記載である Dall (1873) には殼形態に関す る記述はないが，本種の模式標本を検討した Davidson (1888) が殼の外形について記載している. それによれば, L. adamsi の殼は縦に長い長方形で，殼前縁に向けて殼幅 がわずかに広くなり，款前縁は直線に近いと記録されてい る. Hatai (1937) は, L. shantungensis は細長い四辺形で, 殻の両側縁は平行, 殼前縁は丸みがあると記載し, これら 殼外形の特徴をL. adamsi との相違点のひとつにあげた. しかし，これら殼外形の相違点は，韓国産標本に見られた 
殼外形の個体变異の範囲内に含まれており, Davidson (1888) の記述は韓国産標本のうち背殼長 $50 \mathrm{~mm}$ 以上の大 型個体の特徴に近く, Hatai (1937) の記載は背殻長 $50 \mathrm{~mm}$ 以下の小型個体の特徴と一致する.

\section{溝 (grooves) の有無}

Hatai (1937) は, L. shantungensis の腹殼には殼後縁の嘴 状部から殼前縁にかけて 2 本の溝 (grooves) があると記載 しており，これをL. adamsi との壳外形の相違点にあげて いる.これに対して, 菅野 (1980) は有明海産標本にはその ような溝が見られないことから，L. shantungensis とは形態 的に異なるのではないかと考えた。しかし, Emig \& Hammond (1981) あ指摘するとおり，シャミセンガイ類の殼表 には殼内部にある siphonal ribs の構造を反映した不規則な しわが入ることがあり，L. shantungensis の模式標本ではそ れが特に顕著に見られた可能性が高い，今回得られた韓国 産標本に関して, 溝 (grooves) の有無を確認したところ, 腹殼表面には顕著な溝は見られず, 菅野 (1980) らが記述 している有明海産標本の形態的特徴と何ら違いはなかっ た.

\section{殼の色彩}

Davidson (1888) は L. adamsi の朝鮮半島産模式標本打 よび台湾産標本（産地： near the shore, off the Island of Formosa) を検討し, 殼表の色は淡黄色 (light yellow) また は黄褐色 (brownish yellow) と記載している. Hatai (1937) は, この記載を基に, L. shantungensis の凯表の色が暗赤色 (dull-light-red) であることから，L. adamsi と異なる点のひ とつにあげた，本研究で得ら机た韓国産標本は，すべてが 赤褐色をしており， Davidson (1888) の記述よりもむしろ Hatai (1937) の記載したL. shantungensis の殼色に近い.し かし, Emig \& Hammond (1981) によればL. adamsi の壳色 は黄褐色から暗赤褐色までと变異の幅が広いため, 種を識 別する形質にはならない.

なお，Dall (1921) はE. S. Morse が日本（産地：Simabara; Akashi; Higabukanseki, Higo）で採集した標本を検討し，そ れぞれL. adamsi に同定している. しかし, Emig \& Hammond (1981) は, Dall (1921)により検討された日本産の標 本はすべて, 赤褐色に変色したミドリシャミセンガイであ ることを確認している．倉持ら (2001) は Dall (1921) の記 述を基に, 過去にはオオシャミセンガイが瀬戸内海 (明石) にも生息していたとしたが，現在のところ有明海と天草以 外にオオシャミセンガイの生息が確認された報告例はな い.

\section{背殼の殼幅/殼長比}

菅野 (1980) と山口(1980) は，有明海の個体と Hatai (1937) が計測した中国山東省産標本とでは, 殼長と殼幅の 比率が異なることを指摘している。 そこで, 韓国産標本に

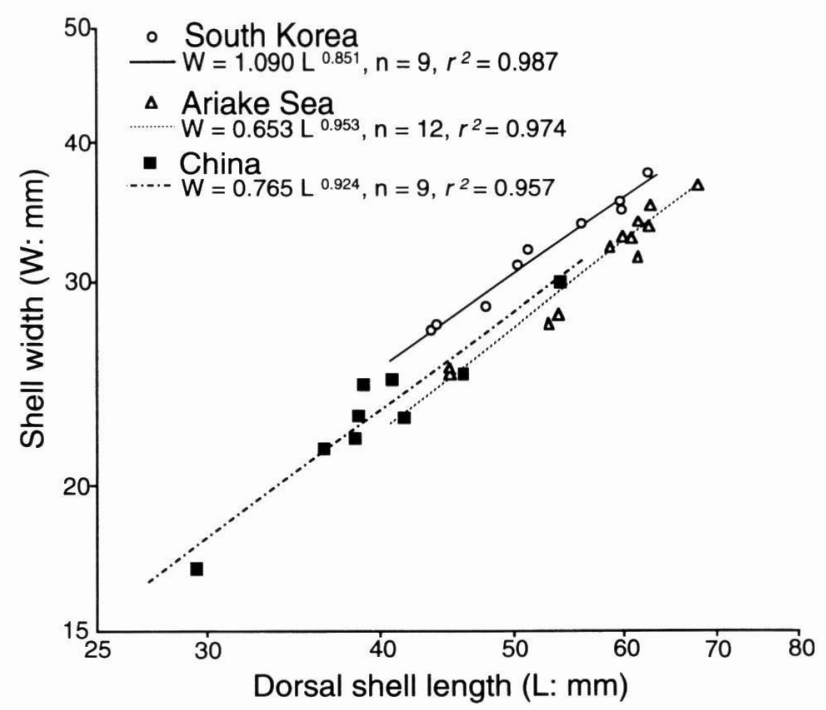

Fig. 3. Double logarithmic scatter plot for the relationship between dorsal shell length and shell width of Lingula adamsi collected from South Korea, Japan (Ariake Sea), and China.

おける背殻の殼幅/款長比を, 菅野 (1980) による長崎県神 代海岸標本, 山口 (1980) による天草松島標本, および著者 の一人 (遠藤) が所有する福岡県柳川標本 2 個体の計測値 と比較した (Fig. 3)。 その結果, 菅野 (1980) らが指摘する とおり, 有明海産標本は韓国産標本に比べて同サイズでも 背殼の殼幅/殼長比が小さいことが明らかになった。また， Hatai (1937) 押よび Emig \& Hammond (1981)による中国 産標本の計測值と比較したところ, 中国産標本は有明海産 標本と韓国産標本の中間的な值を示した (Fig. 3)。殼幅と 殼長について平均成長式 (reduced major axis) の傾きと切 片の検定を行ったところ, 傾きでは有意の差は見られな かったが, 切片の差に抢いて有明海-韓国 $(K=17.87)$, 中 国一韓国 $(K=5.27)$ 間で統計的に有意の差が見られた（検 定方法は速水・松隈 1971 に従った).

しかし，シャミセンガイ類の殼幅と殼長の関係は同種の 地域個体群間でも值が大きく異なること (Emig \& Hammond 1981) や, ミドリシャミセンガイでは同一個体群内 でも個体によって殼幅/殼長比は正・負・等成長のすべて が見られること (Hammond \& Kenchington 1978)などか ら，オオシャミセンの殼幅/殼長比の差異だけで有明海の 集団之韓国の集団が別種であると判断するのは困難であ る.

\section{遺伝学的比較}

韓国と有明海のシャミセンガイ集団間の遺伝的变異を調 べるため, 韓国産標本 10 個体 (IGPS No. 109238-1～8, 109237, 109239) について, mtDNA の $\operatorname{cox} 1$ 遺伝子の一部 （655 塩基対）の塩基配列を決定し, 福岡県柳川産オオシャ ミセンガイおよびミドリシャミセンガイの解析結果 (Endo 
Table 1. Pairwise comparison of coxl sequence variation among individuals of Lingula. Number of nucleotide (lower triangle) and amino acid (upper triangle) differences in the 655 bp coxl region between sequence pairs are shown. IGPS No. 109237, 109238-1 to 8, and 109239 are specimens of $L$. adamsi from South Korea. The specimens of both $L$. shantungensis and $L$. anatina are from the Ariake Sea, Japan. Accession numbers for the DNA sequences stored in the DDBJ/Genbank/EMBL databases are also indicated.

\begin{tabular}{|c|c|c|c|c|c|c|c|c|c|c|c|c|c|}
\hline & $109238-1$ & $109238-2$ & $109238-3$ & $109238-4$ & $109238-5$ & $109238-6$ & $109238-7$ & $109238-8$ & 109237 & 109239 & L. shantungensis & L. anatina & Accession no. \\
\hline IGPS $109238-1$ & & 0 & 0 & 0 & 0 & 0 & 0 & 0 & 0 & 0 & 4 & 40 & AB128055 \\
\hline IGPS $109238-2$ & 4 & & 0 & 0 & 0 & 0 & 0 & 0 & 0 & 0 & 4 & 40 & AB128056 \\
\hline IGPS $109238-3$ & 3 & 1 & & 0 & 0 & 0 & 0 & 0 & 0 & 0 & 4 & 40 & AB128057 \\
\hline IGPS $109238-4$ & 3 & 1 & 0 & & 0 & 0 & 0 & 0 & 0 & 0 & 4 & 40 & AB128058 \\
\hline IGPS $109238-5$ & 3 & 1 & 0 & 0 & & 0 & 0 & 0 & 0 & 0 & 4 & 40 & AB128059 \\
\hline IGPS $109238-6$ & 4 & 2 & 1 & 1 & 1 & & 0 & 0 & 0 & 0 & 4 & 40 & AB128060 \\
\hline IGPS $109238-7$ & 4 & 2 & 1 & 1 & 1 & 2 & & 0 & 0 & 0 & 4 & 40 & AB128061 \\
\hline IGPS $109238-8$ & 10 & 9 & 8 & 8 & 8 & 9 & 9 & & 0 & 0 & 4 & 40 & AB128062 \\
\hline IGPS 109237 & 5 & 3 & 2 & 2 & 2 & 3 & 3 & 10 & & 0 & 4 & 40 & AB128063 \\
\hline IGPS 109239 & 4 & 2 & 1 & 1 & 1 & 2 & 2 & 9 & 3 & & 4 & 40 & AB128054 \\
\hline L. shantungensis & 7 & 7 & 6 & 6 & 6 & 6 & 7 & 13 & 6 & 7 & & 41 & AB056459 \\
\hline L. anatina & 178 & 178 & 178 & 179 & 178 & 178 & 177 & 183 & 177 & 178 & 184 & & AB056460 \\
\hline
\end{tabular}

et al. 2001）と比較した．塩基配列の決定は，エ夕ノール固 定された肉茎内部の組織からCTAB 法を用いて抽出した 全 DNA を鋳型として, PCR 法で目的断片を増幅した後, ダイレクトシーケンス法によって両ストランドの塩基配列 を決定した（プライマーの配列などについては Endo et al. (2001) を参照).

その結果, 韓国産個体群の塩基配列は, 柳川産個体の配 列と非常によく似ていることが明らかになった，すなわ ち, アミノ酸レベルでは解析した 218 残基のうち 4 残基 （約 1.8\%）の相違が見られたのみであった（韓国産オオ シャミセンガイと柳川産ミドリシャミセンガイでは同じ領 域で 40 残基, 約 $18 \%$ 異なる; Table 1).なお, ミドリシャ ミセンガイを含む腕足動物の mtDNA では, 他の前口動物 と同じ変則遺伝暗号が使われていることが推定されており (Saito et al. 2000), ここでも前口動物型の変則暗号を翻訳 に用いた。 また, 塩基配列においても，韓国産標本と柳川 産標本間で 655 の塩基のうち 6 塩基から 13 塩基（約 0.9 2.0\%) のみ異なっていた（柳川産ミドリシャミセンガイと 韓国産オオシャミセンガイの違いは $177 \sim 183$ 塩基, 約 27 29\%; Table 1).これらの変異はいずれも, ミドリシャ ミセンガイでは一つの個体群サンプル中の変異の幅におさ まる. たとえば柳川産標本群 28 個体間の変異は, アミノ酸 およびヌクレオチドレベルでそれぞれ $6.0 \%$ と $4.0 \%$ であ る (Endo et al. 2001). したがって, オオシャミセンガイの 集団内変異がミドリシャミセンガイの集団内変異と変わら ないと仮定すれば, 韓国産標本と柳川産標本を別種とする 積極的根拠はないように思われる.

一方, 比較に使用した柳川産標本自体が, 韓国からのご く最近の移入個体である可能性も否定できない.しかし, 今回比較した韓国産 10 個体は, すべて同一のアミノ酸配 列を有しており（ヌクレオチドレベルの変異はすべて同義 置換), 柳川産個体とは明瞭に区別される (Table 1).この ことは韓国集団と柳川集団がわずかではあるが，ある程度 遺伝的に分化していることを示唆する. 今後より多くの標 本による検証が必要ではあるが, 現時点では柳川産標本が
移入個体である可能性は低いと考えられる.

\section{考 察}

Emig and Hammond (1981)により, L. shantungensis は L. adamsi のシノニムと指摘されたが, その後も日本では 有明海産オオシャミセンガイの学名として広くL. shantungensisが使われてきた. Hatai $(1937,1940)$ は, 款の外 形, 殼表面の色, および構造（腹殼表面にある 2 本の溝な ど）により，L. shantungensis は L. adamsi と明確に分けら れるとした. しかし, 本研究では, Hataiにより指摘された 両種の形態的特徵の差異は, 韓国産個体群内の個体変異の 幅にとどまることが確認され, Emig \& Hammond (1981) の結論を支持した.

また，菅野 (1980) と山口 (1981) は Hatai (1937) を根拠 にして, 有明海の個体と中国の個体では若干形態が異なる ため, 両者は別種か別亜種の可能性があるとした。菅野ら により指摘された殸幅/殼長比の差については, 確かに中 国・韓国・有明海産の標本群間で有意の差が見られたもの の, シャミセンガイ類の殼幅/殼長比は個体群内の変異が 大きいことが明らかにされており, この差をもって有明海 産オオシャミセンを韓国・中国産オオシャミセンと別種と 結論づけるのは困難である. さらに, 遺伝子の検討におい て韓国・有明海産標本間の変異の幅は小さく, ミドリシャ ミセンガイの個体群内の変異の幅におさまることから, 両 集団を別種とする積極的な根拠は得られなかった。

今回, 韓国で採集された検討標本の産地は $L$. adamsi の 模式産地に近く，この韓国産標本を地理的な理由からも積 極的に L. adamsi に同定するならば，遺伝子の解析結果か ら有明海の個体群もL. adamsi に同定される. Emig \& Hammond (1981) の結論に従えば, L. shantungensis は $L$. adamsi のシノニムとなることから, オオシャミセンガイ L. adamsi は有明海〜朝鮮半島〜中国大陸沿岸に分布する 種であると考えられる. 
謝 辞：金敬源氏と金京完氏をはじめとする韓国環境 NGO の 方々，および日韓共同干潟調査団の方々には，韓国での調査にお いて様々な便宜を図っていただいた。福岡県柳川産標本の採集で は, 九州大学理学部の故柳田壽一教授, および福岡県水産海洋技 術センタ一有明海研究所の寿崎洋一所長, 秋本恒基氏, 林宗徳氏 （いずれむ当時）にご助力いただいた．岡山大学農学部の福田宏助 教授には, 山口県で採集されたオオシャミセンガイ壳に関する情 報を提供していただいた。 また，高知大学理学部の近藤康生教授 と匿名の 2 名の査読者には数多くの有益なご指摘をいただいた. これらの方々に厚くお礼申し上げます。なお本研究費の一部とし て, 佐藤は文部省科学研究費補助金 (若手研究 B: No. 15740308) を, 山下と佐藤はトヨ夕財団市民社会プロジェクト助成金および 高木仁三郎市民科学基金調查研究助成金を使用させていただい た. 記して感謝の意を表します。

\section{引用文献}

Adams, A. 1863. On the genera and species of Recent brachiopods found in the Sea of Japan. Annals and Magazine of Natural History, Including Zoology, Botany and Geology, Third Series, 11: 98-101.

Cusack, M., A. Williams and J. O. Buckman 1999. Chemicostructural evolution of linguloid brachiopod shells. Palaeontology, 42: 799-840.

Dall, W. H. 1873. Catalogue of the recent species of the class Brachiopoda. Proceedings of the Academy of Natural Sciences of Philadelphia, 1873: 177-204.

Dall, W. H. 1921. Annotated list of the recent brachiopods in the collection of the United States National Museum, with descriptions of thirty-three new forms. Proceedings of the United States National Museum, 57(2314): 264-377.

Davidson, T. 1888. A monograph of the Recent Brachiopoda. Part III. The Transactions of the Linnean Society of London, Series 2, 4: 183-248.

Emig, C. C. 1982. Taxonomie du genre Lingula (Brachiopodes, Inarticules). Bulletin du Muséum National d'Histoire Naturelle. Série 4, Section A, Zoologie, Biologie et Écologie Animales, 3-4: 337-367.

Emig, C. C. and L.S. Hammond 1981. On the status of Lingula tumidula Reeve, L. adamsi Dall, and L. shantungensis Hatai (Brachiopoda, Inarticulata). Bulletin of Marine Science, 31: 37-45.

Endo, K., T. Ozawa and S. Kojima 2001. Nuclear and mitochondrial gene sequences reveal unexpected genetic heterogeneity among northern Pacific populations of the brachiopod Lingula anatina. Marine Biology, 139: 105-112.

Hammond, L. S. and R. A. Kenchington 1978. A biometric case for revision of the genus Lingula (Brachiopoda: Inarticulata) from
Queensland, Australia. Journal of Zoology, London, 184: 53-62.

Hatai, K. 1937. On some recent brachiopods from Eastern Shantung, China. Bulletin of the Biogeographical Society of Japan, 7: 317-324.

Hatai, K. 1940. The Cenozoic Brachiopoda of Japan. Science Reports of the Tohoku Imperial University, Series 2, 20: 1-413.

Hatai, K. 1954. Check list of Japanese Tertiary and Pleistocene Brachiopoda. Tokyo Kyoiku Daigaku, Science Report, Section C, 3: 99-139.

速水 格・松隈明彦 1971. 化石の計測と統計一アロメトリーと 個体変異の解析一. 九州大学理学部研究報告 (地質学), 10: 135160.

糸魚川淳二・奥村好次 - 西本博行 1976. 瑞浪層群の腕足動物化 石相. 瑞浪市化石博物館報告, 3: 41-54.

倉持卓司・木村キワ・藤本和恵 2001 . 日本周辺海域産シャミセ ンガイ属の再検討. 南紀生物, 43: 112-116.

Ohara, S. 1969. Discovery of Lingula from the Oligocene Shimokine Formation of the Uryu coal-field in central Hokkaido. Journal of the Geological Society of Japan, 75: 387-388.

Ponder, W. F. 1998. Superfamily Galeommatoidea. In Mollusca, Part A: The Southern Synthesis. Fauna of Australia. Vol. 5, Beesley, P. L., G. J. B. Ross and A. Wells (eds.), CSIRO Publishing, Melbourne, pp. 316-318.

Saito, M. 2001. Cenozoic Brachiopoda. In The Database of Japanese Fossil Type Specimens Described during the 20th Century, Ikeya, N., H. Hirano and K. Ogasawara (eds.), Palaeontological Society of Japan, Tokyo, pp. 435-448.

Saito, M., S. Kojima and K. Endo 2000. Mitochondrial COI sequences of brachiopods: genetic code shared with protostomes and limits of utility for phylogenetic reconstruction. Molecular Phylogenetics and Evolution, 15: 331-344.

Shimakura, M. and K. Hatai 1939. On a fossil species of Lingula from Hirobuti-mura Miyagi-ken. Journal of the Geological Society of Japan, 46: 401-405.

菅野 徹 1980. 有明海のオオオシャミセンガイ. 合津臨海実験所 報 Calanus, 7: 13-32.

内海富士夫 1956. 原色日本海岸動物図鑑, 保育社, 東京, $144 \mathrm{pp}$. 和田恵次・西平守孝 - 風呂田利夫 ・ 野島 哲 - 山西良平・西川輝 昭・五嶋聖治・鈴木孝男・加藤 真・島村賢正・福田 宏 1996. 日本における干潟海岸とそこに生息する底生生物の現 状. WWF-Japan サイエンスレポート，3: 1-182.

山口隆男 1980. 天草松島のオオシャミセンガイ. 合津臨海実験所 報 Calanus, 7: 33-38.

柳田寿一・黒岩理香・内藤源太郎・土井英治 1995. 三畺系美袮 層群より産出した Lingula 属腕足類. 九州大学理学部研究報告 (地球惑星), 19: 1-9. 